\title{
Application of otolith morphometry for the study of ontogenetic variations of Odontesthes argentinensis
}

\author{
Fernanda Gabriela Biolé $\mathbb{D}$ - Roberta Callicó Fortunato • \\ Gustavo Ariel Thompson - Alejandra Vanina Volpedo
}

Received: 21 March 2019/Accepted: 12 August 2019

(C) Springer Nature B.V. 2019

\begin{abstract}
The study of otolith morphometry is a tool widely used in numerous studies of fish populations (fish stocks, taxonomic, ecological, ontogeny, among others). The aim of this study was to detect ontogenetic variations in the otolith of Odontesthes argentinensis through the application of traditional and geometric morphometry and the association of these variations with ecological and trophic habits of the species. Fish ( 52 to $360 \mathrm{~mm}$ TL) were collected seasonally between years 2013-2016 in the southwest coast of the Atlantic Ocean (36³9'30.96"S - 56 40'40.09'W). Otolith shape indices (circularity, rectangularity, aspect ratio and surface occupied by sulcus) and Fourier descriptors were measured and compared through ontogenetic stages (I, II and III). The three stages analysed in the present study were differentiated by both traditional and geometric morphometry. The four analysed indices showed significant differences between stages (ANOVA Kruskal Wallis test, $P<0.001$ ) and a simultaneous analysis of the morphometric variables also
\end{abstract}

F. G. Biolé $(\bowtie) \cdot$ R. Callicó Fortunato • G. A. Thompson • A. V. Volpedo

CONICET, Universidad de Buenos Aires, Instituto de Investigaciones en Producción Animal (INPA), Av. Chorroarín 280, C1427CWO Buenos Aires, Argentina

e-mail: fernandabiole@ conicet.gov.ar

e-mail: fernandabiole@hotmail.com

A. V. Volpedo

Centro de Estudios Transdisciplinarios del Agua (CETA), Facultad de Ciencias Veterinarias, Universidad de Buenos Aires, Buenos Aires, Argentina showed significant differences (Hotelling's $\mathrm{T}^{2}$ $<0.001)$. The quadratic discriminant analysis performed on the Fourier descriptors showed a clear separation for each defined group. Therefore, the use of both methodologies simultaneously could be considered robust to evaluate the ontogenetic variations in this species. The observed changes could be associated to changes in the habitat throughout its development, to the sexual maturity of fish and to dietary shifting of these organisms.

Keywords Odontesthes argentinensis • Argentina . Fourier analysis $\cdot$ Morphometric ontogenetic indices

\section{Introduction}

Otoliths are calcareous concretions located in the inner ear of fish and are species specific (Campana 1999; Assis 2000; Tuset et al. 2003a). Otolith shape is a tool widely used for taxonomic studies (Volpedo and Echeverría 1999; Tombari et al. 2005; Tombari et al. 2010; Volpedo and Vaz dos Santos 2015; Jawad et al. 2017), fish stock identification (Avigliano et al. 2015a), nursery areas identification (Avigliano et al. 2016, 2017), discrimination among closely related species (Callicó Fortunato et al. 2014; Avigliano et al. 2015b, 2018), ecological studies (Avigliano et al. 2014, 2015c) and ontogenetic studies (de Carvalho et al. 2015; Callicó Fortunato et al. 2017).

Sagittae otoliths permit the analysis of different aspects of fish biology and their environment (MoralesNin 1987; Radtke and Shafer 1992). General form of 
otolith is associated with ecological characteristics such as depth, habitat, type of locomotion and feeding (Wilson 1985; Gauldie and Crampton 2002; Lombarte et al. 2003; Volpedo and Echeverría 2003; Sadighzadeh et al. 2014; Tuset et al. 2015). In this sense, otoliths' traditional morphometric analysis has allowed identifying different ecological aspects of fish species. The shape, margins and rostrum of otoliths were used by Volpedo and Echeverría (2003) to identified three ecomorphological groups according to the use of the water column (fish associated with soft and hard substrates, and pelagic fish) from the Argentinian shelf. Volpedo et al. (2008) determined that swimmer fish have a common sagittae morphological pattern: oblong shape, marked rostrum and a considerable sulcus area (>20\% of the otolith surface, approximately), while fish that make short vertical migrations present rostrum, excisure and antirostrum slightly developed. Lombarte et al. (2010) suggested that there is a clear correspondence between relative otolith size and shape of nototheniids (pelagic and benthic species). In addition, the traditional morphometry has been used to evaluate changes during the development of fish (Volpedo and Echeverría 1999; Waessle et al. 2003; De La CruzAgüero et al. 2012; Vignon 2012; de Carvalho et al. 2015). These authors observed morphometric changes in otoliths related to sexual maturation, diet change, or habitat use by swimmer fish. These morphometric variations are due to physiological changes or to endogenous factors that make calcium carbonate to precipitate differently in juveniles and adults.

On the other hand, geometric morphometry, allows to recognize the existence of groups through the identification of landmarks (anatomical loci that do not alter their topological position) and outlines (Fourier contours) in the profile of different organisms and structures (Turan 2000; Ponton 2006; Burke et al. 2008; Vignon and Morat 2010; Avigliano et al. 2016). The comparison of the otolith shape in fish by geometric morphometric methods (commonly known as "otolith shape analysis") is widely used to study the population structure of different fish species (Orlov and Afanasyev 2013; Valentin et al. 2014; Harbitz and Albert 2015; Cresson et al. 2015). Otolith shape analysis has allowed to study the discrimination of spawning groups (Gadus morhua; Galley et al. 2006), to separate population stocks (Tracey et al. 2006; Burke et al. 2008; Vasconcelos et al. 2018) and to identify distinct growth phases in fish like Anchoa tricolor and different engraulid species (Ponton 2006; de Carvalho et al. 2015). Ontogenetic otolith shape changes during fish growth have been described and used to identify age (Cardinale et al. 2004), sex and maturity stage (Bird et al. 1986; Lombarte and Castellón 1991; Piera et al. 2005). de Carvalho et al. (2015) determined that changes in the otoliths shape of $A$. tricolor were associated with the changes in swimming ability and sexual maturation during growth. Moreover, Vignon (2012) related ontogenetic changes in otolith shape of a coral reef fish with a shift in habitat use.

The association of traditional morphometry and geometric studies makes it possible to expand the use of otoliths as key elements for understanding species and populations (Rohlf and Marcus 1993; Monteiro et al. 2005; Vignon 2012). As mentioned before, both methods have been used to evaluate otolith changes during the development of fish; but studies that applied them together are very scarce.

One of the most ecologically and economically important marine coastal species on the southwest coast of the Atlantic Ocean is Odontesthes argentinensis. This species is distributed along the southwest coast of the Atlantic Ocean, between Rio de Janeiro, Brazil $\left(22^{\circ} \mathrm{S}\right)$ and Rawson, Argentina (43ㅇ) (Dyer 2000, 2006; Di Dario et al. 2013). It is present in the diet of marine mammals and seabirds (Silva Rodríguez et al. 2005; Tombari et al. 2005) and is considered a significant economic resource for in local fisheries in southern Brazil, Uruguay and Argentina (De Buen 1953; Chao et al. 1985; Sampaio 2006; Llompart et al. 2013, 2017). In Argentina, $O$. argentinensis is exploited by recreational and artisanal fisheries along the coast of Buenos Aires province (Llompart et al. 2012).

Tombari et al. (2005), studied the ontogenetic variability of the otolith of $O$. argentinensis through morphology, however, there are no studies on their morphometry. The objective of this work is the detection of ontogenetic variations in the otolith of $O$. argentinensis through the application of traditional and geometric morphometry, and the association of these variations with the ecological and trophic habits of the species.

\section{Materials and methods}

Study area and fish sample collection

Specimens of Odontesthes argentinensis were obtained seasonally from artisanal catches with gill nets or rods 
between years 2013-2016 in the coastal city of La Lucila del Mar (36³9'30.96”S - 56 40'40.09”W), Buenos Aires province - Argentina - South America (Fig. 1). A total of 290 individuals were collected and taken to the laboratory. Total and standard length (TL and SL in $\mathrm{mm}$ ) were recorded and their sagittae otoliths were removed. A wide range of sizes were sampled (52 to $360 \mathrm{~mm} \mathrm{TL}$ ), so as to have a large number of individuals of the different development stages. After extraction and cleaning, the inner face of left sagittae otoliths was photographed with a digital camera attached to a stereomicroscope (Leica® EZ4 HD).

\section{Traditional morphometric analysis}

For the study of traditional morphometry, images were analysed and morphometric variables were measured using an image processing system (Image-Pro Plus $4.5 \circledR)$. The variables registered were: otolith length $(\mathrm{OL})$, otolith height $(\mathrm{OH})$, otolith perimeter $(\mathrm{OP})$ and sulcus perimeter $(\mathrm{SP})$ in $\mathrm{mm}$; and otolith area $(\mathrm{OA})$ and sulcus area (SA) in $\mathrm{mm}^{2}$ (Fig. 2). Afterwards, four indices were calculated using these variables: $i$ ) circularity $\left(\mathrm{OP}^{2} / \mathrm{OA}\right)$, providing information on the complexity of the otolith, taking a minimum value of $4 \pi$ (Tuset et al. 2003b; Lombarte and Tuset 2015); ii) rectangularity $(\mathrm{OA} /[\mathrm{OL} * \mathrm{OH}])$, giving information on the approximation to a rectangular or square shape, being 1 a perfect rectangle or square, taking the value $\pi / 4$ for circular objects and smaller values for slender, curved objects (Wu et al. 2008; Lombarte and Tuset 2015); iii) aspect ratio $(\mathrm{OH} / \mathrm{OL})$, used to distinguished long and thin objects from roughly square or circular objects (Tuset et al. 2003b), and iv) percentage of the otolith area occupied by the sulcus (SA/OA) (Avigliano et al. 2014; Volpedo and Vaz dos Santos 2015). Indices were corrected to eliminate possible allometry effects in otolith shape related to fish body size, for a proper comparison between groups; the formula proposed by Lleonart et al. (2000): $y^{\prime}=y_{i}{ }^{*}\left(x_{0} / x_{i}\right)^{b}$ was used, in which $y^{\prime}$ is the corrected predictive variable, $\mathrm{y}_{\mathrm{i}}$ is the original value of the obtained index, $\mathrm{x}_{0}$ is a referential standard length (SL) value $\left(\mathrm{SL}_{\text {minimum }}=44 \mathrm{~mm}\right), \mathrm{x}_{\mathrm{i}}$ is the original $\mathrm{SL}$ value, and $b$ is the Huxley coefficient of each regressioned index to SL.

Three development stages were defined according to Tombari et al. (2005), as follow: stage I: individuals $\leq 130 \mathrm{~mm}$ TL $(n=92)$; stage II: individuals $>130 \mathrm{~mm}$ $\overline{\mathrm{TL}}$ and $\leq 210 \mathrm{~mm} \mathrm{TL}(n=124)$; and stage III: individuals $>210 \mathrm{~mm}$ TL $(n=74)$. Tombari et al. (2005) also identified a stage IV: (TL $>280 \mathrm{~mm}$ and $\leq$ $320 \mathrm{~mm}$ ). In the present study, due to the low number of individuals $>280 \mathrm{~mm}$ TL $(n=20)$, stages III and IV (ca. Tombari et al. 2005) were considered one single group (stage III).

The four shape indices were compared among previously identified development stages by one-way analysis of variance (ANOVA). Since parametric assumptions of normality (Shapiro-Wilks test) and homogeneity of variance (Levene's test) could not be met, the KruskalWallis nonparametric ANOVA tests were used. Stage medians were compared by Dunn's multiple comparison test. Finally, a multivariate analysis of variance (MANOVA) with Hotelling's $\mathrm{T}^{2}$ test was applied to evaluate differences among stages considering all morphometric variables simultaneously. All differences were tested at a probability $(\alpha)$ of 0.05 .

\section{Otolith shape analysis}

To study the otolith shape differences among stages, a Fourier shape analysis was performed to a subsample of the individuals $(n=247)$ divided in the same way as in the traditional morphometry analysis (stage I: $n=97$; stage II: $n=91$ and stage III: $n=59$ ). For this analysis, otolith images were digitalized using the Shape program (SHAPE software ver.1.3, Iwata and Ukai 2002). First, using the chain coding algorithm, the numerical contour of each otolith was extracted. Then the elliptical Fourier analysis (EFA) was performed obtaining data for 20 harmonics to explain the original shape of each otolith (Steer and Fowler 2014). Finally, the number of harmonics required to explain otoliths outlines was estimated using the average Fourier spectrum (FP) as described by Steer and Fowler (2014). Of the 20 harmonics analysed, the first 8 represented $99.99 \%$ of the mean cumulative power (Fig. 3), so those were the ones used for later analysis.

Each of these eight harmonics was characterized by four coefficients (a, b, c, d), but the first three (a1, b1, c1) were constant for every sample (Steer and Fowler 2014); therefore, the total number of shape descriptors for each otolith was: $(4 *$ number of harmonics -3$)=$ 29. Each descriptor was treated as an independent variable. A Quadratic discriminant analysis (QDA) was performed to test the differences in shape of the three defined development stages, using the shape descriptors mentioned before, since this analysis does not require 


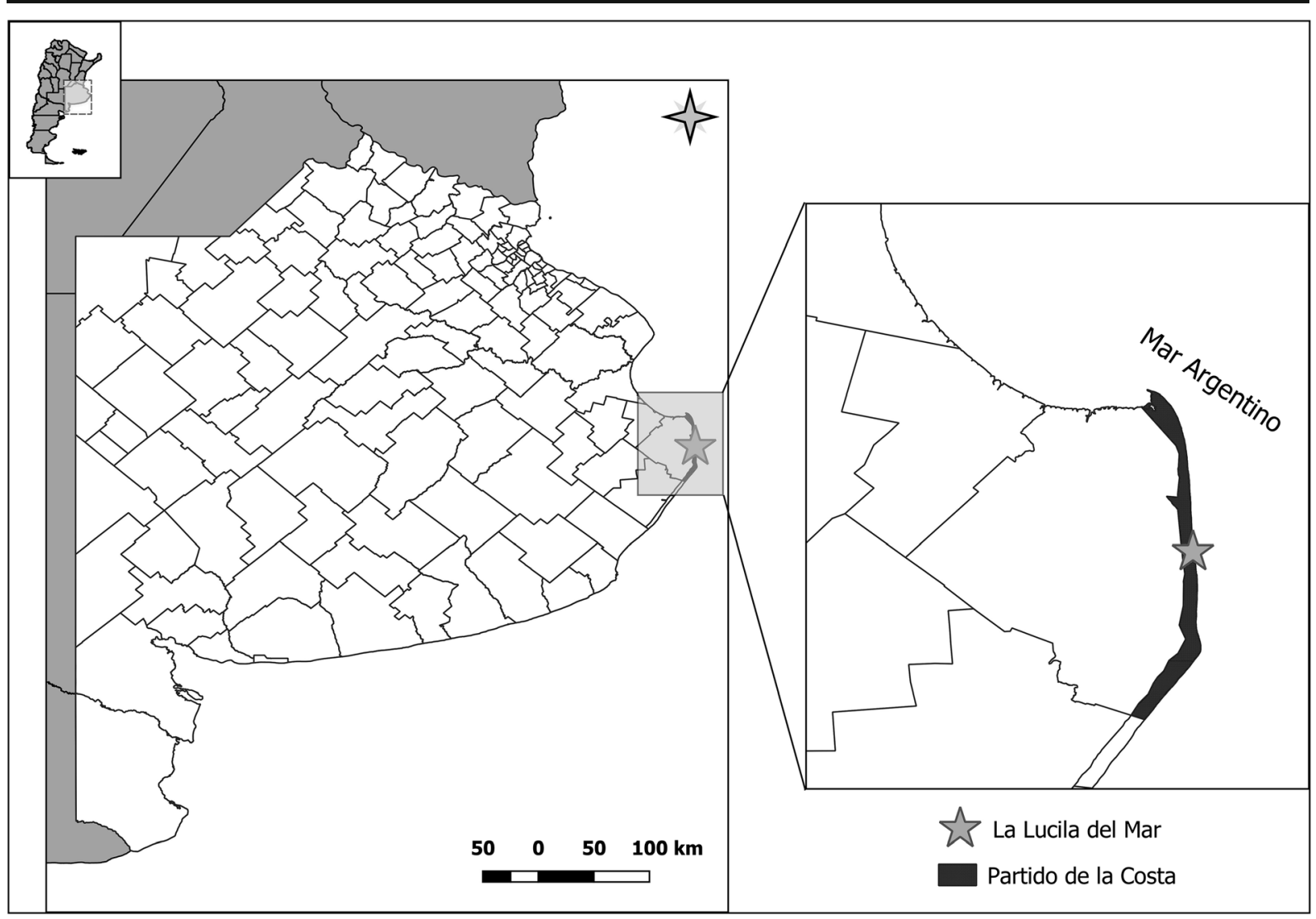

Fig. 1 Location of Odontesthes argentinensis sampling site in the coast of Buenos Aires province (La Lucila del Mar: grey star) at Partido de La Costa

the data to meet the assumptions of homogeneity of variance and multivariate normality (Mohan et al. 2012). An error was estimated for each analysed group after obtaining the classification matrix.

\section{Results}

Traditional morphometric analysis

The four analysed indices showed significant differences among stages (Table 1). Older specimens (stage III: TL > $210 \mathrm{~mm}$ ) showed significantly lower circularity and higher percentage occupied by the sulcus than younger specimens. Stage II individuals showed significant higher values of rectangularity and aspect ratio indices, than stages I and III, indicating that stage II otoliths were more oval and larger than wider with regard to other stages (Table 1). When analysing morphometric variables simultaneously, the three stages differed significantly (Hotelling's $\mathrm{T}^{2}<0.001$ ).
Otolith shape analysis

The quadratic discriminant analysis showed a clear separation for each defined group (Table 2); mean error of the QDA for all groups was less than $4 \%$ (Table 2). When observing the mean shapes $( \pm 2$ standard deviation) of each group, smaller individuals (stage I) had a more rounded otolith shape with a long rostrum an almost non-existent antirostrum; medium-size specimens (stage II) had a more round-oval otolith shape with a short rostrum, and stage III individuals had a more oval-elongate shape with moderate rostrum but no antirostrum present (Fig. 4).

\section{Discussion}

The results showed the existence of morphometric variations in the otoliths of $O$. argentinensis between 52 and $360 \mathrm{~mm}$ total lengths, coinciding with the results 
Fig. 2 Left sagitta otolith of Odontesthes argentinensis. Features and measured variables: OL: otolith length; $\mathrm{OH}$ : otolith height; OA: otolith area; SA: sulcus area; otolith perimeter (dash white line); sulcus perimeter (continuous black line)

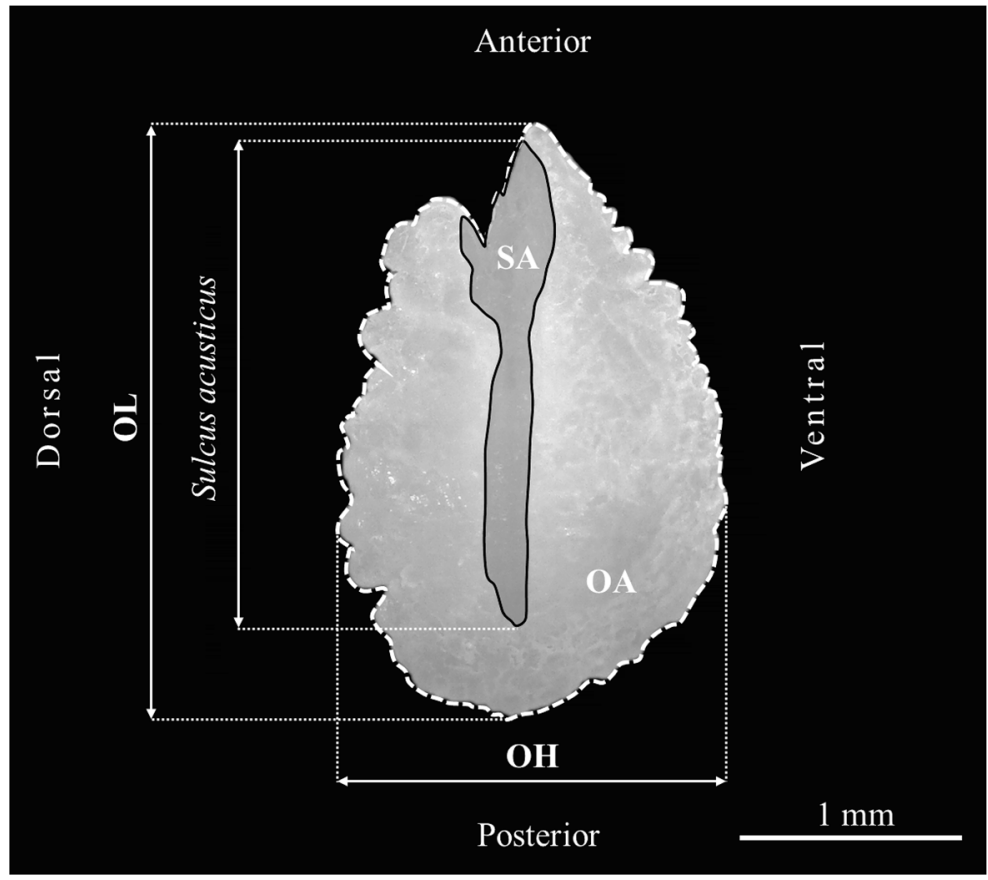

obtained by Tombari et al. (2005) based on the otoliths morphology of this species.

Differences were determined by traditional morphometry analysing the different morphometric indices. Significantly high circularity values were obtained for stages I and II indicating high edge complexity and circular shape, which is typical of the larval stage (Hüssy 2008; de Carvalho et al. 2015; Joh et al. 2015), while lowest circularity index values were obtained in adult individuals (development stage III). These results agree with those recorded by Callicó Fortunato et al. (2017), for Mugil liza and Liza ramada, which could be

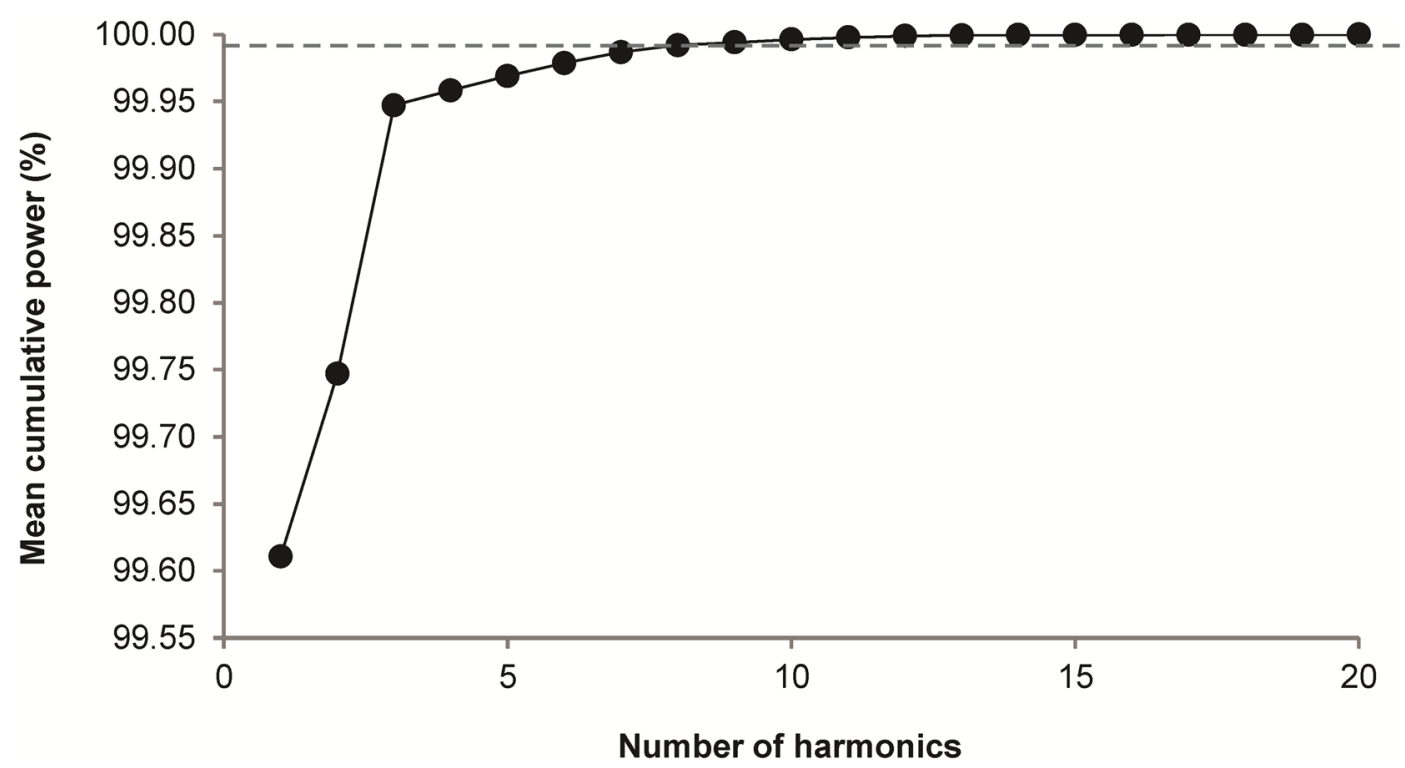

Fig. 3 Fourier mean cumulative power (\%) from harmonics analysed to study otolith shape throughout Odontesthes argentinensis ontogeny. Dash line shows number of harmonics at $99.99 \%$ of cumulative power 
Table 1 Statistical analysis performed for the four morphometric variables: $H=$ Kruskal-Wallis test (medians test). Different letters show significant difference in Dunn multiple comparisons. Significant $p$ values $(p<0.05)$ are indicated in bold

\begin{tabular}{|c|c|c|c|c|c|}
\hline & $\begin{array}{l}\text { Stage I } \\
(n=92) \\
\text { Median }\end{array}$ & $\begin{array}{l}\text { Stage II } \\
(n=124) \\
\text { Median }\end{array}$ & $\begin{array}{l}\text { Stage III } \\
(n=74) \\
\text { Median }\end{array}$ & Statistic $(\mathrm{H})$ & $\mathrm{p}$ \\
\hline Circularity $\left(\mathrm{OP}^{2} / \mathrm{OA}\right)$ & $18.444^{\mathrm{a}}$ & $18.911^{\mathrm{a}}$ & $17.859^{\mathrm{b}}$ & 8.16 & $<0.001$ \\
\hline Rectangularity $(\mathrm{OA} /[\mathrm{OL} \times \mathrm{OH}])$ & $0.597^{\mathrm{a}}$ & $0.694^{\mathrm{b}}$ & $0.584^{\mathrm{a}}$ & 89.94 & $<0.001$ \\
\hline Aspect ratio $(\mathrm{OH} / \mathrm{OL})$ & $0.740^{\mathrm{a}}$ & $0.763^{\mathrm{b}}$ & $0.728^{\mathrm{a}}$ & 7.66 & $<0.001$ \\
\hline Percentage occupied by the sulcus (SA/OA) & $0.161^{\mathrm{a}}$ & $0.157^{\mathrm{a}}$ & $0.168^{\mathrm{b}}$ & 3.59 & 0.032 \\
\hline
\end{tabular}

associated to movements that smaller fish of these species performed to find their development habitats. Circularity was also a good habitat indicator for species like Odontesthes bonariensis, Prochilodus lineatus, Plagioscion ternetzi, Coryphaenoides rupestris, Lophius piscatorius, Argyrosomus japonicus and Scomberesox saurus (Longmore et al. 2010; Agüera and Brophy 2011; Ferguson et al. 2011; Cañás et al. 2012; Avigliano et al. 2015a, 2015c, 2017). Rectangularity and aspect ratio index values indicated that the sagittae of $O$. argentinensis had a more elongated than wide shape, which could be related to swimmer fishes according to Volpedo and Echeverría (2003). Rectangularity was also considered an efficient habitat indicator for several species like Coryphaena hippurus (Duarte-Neto et al. 2008), Gadus morhua (Petursdottir et al. 2006) and Scomberesox saurus (Agüera and Brophy 2011). The difference recorded in the percentage of otolith surface occupied by the sulcus in stage III, might be due to the fact that this index is higher in pelagic and swimmer fish than in fish with demersal habits (Gauldie 1988; Volpedo and Echeverría 2003) and in migratory species than in those that are not (Tuset et al. 2003a, b; Avigliano et al. 2015c). Moreover, fish with larger sulcus have more contact surface with the nervous macula, thus, capturing greater environmental information compared with fish more frequently related to the bottom that present lower sulcus surface (Volpedo and Echeverría 2003; Popper et al. 2005; Jaramillo et al. 2014). Adults of $O$. argentinensis show a benthic feeding habit (Bemvenuti 1990; Martinetto et al. 2005), inhabiting the coast of the Atlantic Ocean (Dyer 2000).

The shape of the silverside fish otolith presented distinctive patterns during each of the development stages: stage I had a rounded otolith with a marked rostrum, stage II presented a more round-oval otolith with a less marked rostrum and stage III presented an otolith with an elongated shape and moderate rostrum (Fig. 2). Due to the pelagic swimming behaviour of the juveniles of $O$. argentinensis, features of stage I otoliths are in agreement with Volpedo and Echeverría (2003), whom determined that the sagittae of pelagic fish possessed a prominent rostrum, a deep V-shaped excisure and ornamented borders. On the other hand, otoliths of the stages II and III show similar characteristics to the sagittae of fish associated with soft substrates (circular or polygonal with rounded borders, poorly developed rostrum) (Volpedo and Echeverría 2003) or to the sagittae of mesopelagic fish that make short vertical migrations (Volpedo et al. 2008). This suggests that otolith morphometrics can reflect the use of the water

Table 2 Cross-classification table of the quadratic discriminant analysis (QDA) for the three defined development stages of Odontesthes argentinensis, based on 29 shape descriptors per otolith obtained by the morphometric Fourier analysis

\begin{tabular}{|c|c|c|c|c|c|}
\hline Development stages & I & II & III & $\begin{array}{l}\text { Sampled individuals } \\
\text { per stage }\end{array}$ & $\begin{array}{l}\text { Estimated Percentage } \\
\text { Error }\end{array}$ \\
\hline I & 94 & 2 & 1 & 97 & $3.1 \%$ \\
\hline II & 0 & 91 & 0 & 91 & $0 \%$ \\
\hline III & 0 & 1 & 58 & 59 & $1.7 \%$ \\
\hline
\end{tabular}


Fig. 4 Mean \pm 2 standard deviation of otolith shapes for the three defined development stages (I, II and III). Black line: mean; light-grey lines: \pm standard deviations

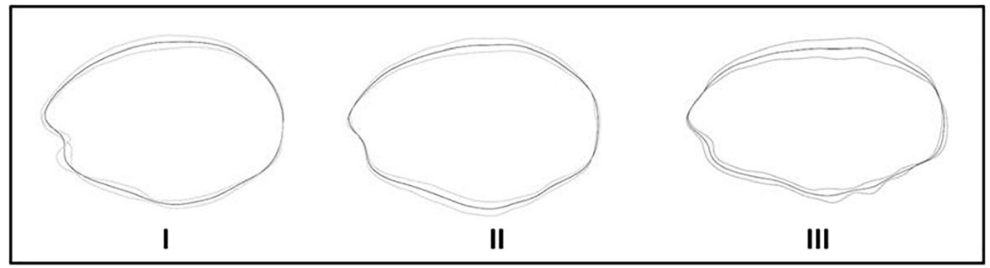

column by the fish during their life cycle, as seen for O. argentinensis.

The variability in otolith shape could be associated with ecological (coastal oceanographic processes, chemical/physical characteristics of water, etc.) and biological (sexual maturity, growth) (Tombari et al. 2005) factors. On the other hand, Hüssy (2008), suggests that the overall shape of the otolith is an ontogenetic process, while the finer details can be modulated by environmental conditions, most particularly related with feeding level, ranging from starvation to ad libitum (Gagliano and McCormick 2004) and food availability (Cardinale et al. 2004). In this sense, the observed changes in stage I, could be due to the fact that the fish have greater swimming habits and feed on plankton (Thompson and Volpedo 2018). In stage II fish broaden their range of prey items by feeding on other organisms associated with the bottom such as Tanaidacea, Polychaeta, Amphipoda and megalopa stage of Crustacea Decapoda larvae (Bemvenuti 1990; Martinetto et al. 2005; Thompson and Volpedo 2018) and these changes in the diet could be reflected in the otoliths shape. On the other hand, stage III includes individuals with the size of first sexual maturation (Bemvenuti 1990; Tombari et al. 2005; Llompart et al. 2013), thus, otolith changes could be associated with displacement habits (de Carvalho et al. 2015; Callicó Fortunato et al. 2017).

The application of morphometric techniques complements the study of morphology to better understand the ontogeny of fish otoliths. Moreover, the simultaneous use of these techniques strengthens the analysis. The morphometric variations observed in the otolith of $O$. argentinensis throughout its ontogeny could be associated to changes in the habitat throughout its development, to the sexual maturity of fish and to the changes in the feeding habits of these organisms.

Acknowledgements Authors are indebted to CONICET (PIP 112-20120100543CO), ANPCyT (PICT 2015-1823), Universidad de Buenos Aires (UBACYT 20020150100052BA) for financial support.

\section{References}

Agüera A, Brophy D (2011) Use of saggital otolith shape analysis to discriminate Northeast Atlantic and Western Mediterranean stocks of Atlantic saury, Scomberesox saurus saurus (Walbaum). Fish Res 110:465-471. https://doi. org/10.1016/j.fishres.2011.06.003

Assis CAdS (2000) Estudo morfológico dos otólitos Sagittae, Asteriscus e lapillus de teleósteos (Actinopterygii, teleostei) de Portugal continental. Universidade de Lisboa, Doctoral Thesis

Avigliano E, Martinez-Riaños F, Volpedo AV (2014) Combined use of otolith microchemistry and morphometry as indicators of the habitat of the silverside (Odontesthes bonariensis) in a freshwater-estuarine environment. Fish Res 149:55-60. https://doi.org/10.1016/j.fishres.2013.09.013

Avigliano E, Comte G, Rosso JJ, Mabragaña E, Della Rosa P, Sanchez S, Volpedo AV, del Rosso F, Schenone NF (2015a) Identification of fish stocks of river Crocker (Plagioscion ternetzi) in Paraná and Paraguay rivers by otolith morphometry. Lat Am J Aquat Res 43(4):718-725. https://doi. org/10.3856/vol43-issue4-full

Avigliano E, Jawad LA, Volpedo AV (2015b) Assessment of the morphometry of saccular otoliths as a tool to identify triplefin species (Tripterygiidae). J Mar Biol Assoc U.K 1-14 https://doi.org/10.1017/s0025315415001101

Avigliano E, Villatarco P, Volpedo AV (2015c) Otolith Sr:ca ratio and morphometry as indicators of habitat of a euryhaline species: the case of silverside Odontesthes bonariensis. Cienc Mar 41(3):189-202. https://doi.org/10.7773/cm.v41 i3. 2464

Avigliano E, Callicó Fortunato R, Biolé F, Domanico A, Simone SD, Neiff JJ, Volpedo AV (2016) Identification of nurseries areas of juvenile Prochilodus lineatus (Valenciennes, 1836) (Characiformes: Prochilodontidae) by scale and otolith morphometry and microchemistry. Neotrop Ichthyol 14(3): e160005. https://doi.org/10.1590/1982-0224-20160005

Avigliano E, Domanico A, Sánchez S, Volpedo AV (2017) Otolith elemental fingerprint and scale and otolith morphometry in Prochilodus lineatus provide identification of natal nurseries. Fish Res 186:1-10. https://doi.org/10.1016/j. fishres.2016.07.026

Avigliano E, Rolón ME, Rosso JJ, Mabragaña E, Volpedo AV (2018) Using otolith morphometry for the identification of three sympatric and morphologically similar species of Astyanax from the Atlantic rain Forest (Argentina). Environ Biol Fish 101(9):1319-1328

Bemvenuti MDA (1990) Hábitos alimentares de peixes-rei (Atherinidae) na regi ao estuarina da Lagoa dos Patos, Rio Grande do Sul, Brasil. Atlantica Rio Grande 12:79-102 
Bird JL, Eppler DT, Checkley DM Jr (1986) Comparisons of herring otoliths using Fourier series shape analysis. Can J Fish Aquat Sci 43:1228-1234

Burke N, Brophy D, King PA (2008) Otolith shape analysis: its application for discriminating between stocks of Irish Sea and Celtic Sea herring (Clupea harengus) in the Irish Sea. ICES J Mar Sci 65(9):1670-1675

Callicó Fortunato R, Benedito Durà V, Volpedo A (2014) The morphology of saccular otoliths as a tool to identify different mugilid species from the northeastern Atlantic and Mediterranean Sea. Estuar Coast Shelf Sci 146:95-101. https://doi.org/10.1016/j.ecss.2014.05.013

Callicó Fortunato R, Benedito Durà V, González-Castro M, Volpedo A (2017) Morphological and morphometric changes of sagittae otoliths related to fish growth in three Mugilidae species. J Appl Ichthyol 33(6):1137-1145. https://doi. org/10.1111/jai.13479

Campana SE (1999) Chemistry and composition of fish otoliths: pathways, mechanisms andapplications. Mar Ecol Prog Ser 188:263-297

Cañás L, Stransky C, Schlickeisen J, Sampedro MP, Fariña AC (2012) Use of the otolith shape analysis in stock identification of anglerfish (Lophius piscatorius) in the Northeast Atlantic. ICES J Mar Sci 69:250-256. https://doi. org/10.1093/icesjms/fss006

Cardinale M, Doering-Arjes P, Kastowsky M, Mosegaard H (2004) Effects of sex, stock, and environment on the shape of known-age Atlantic cod (Gadus morhua) otoliths. Can J Fish Aquat Sci 61:158-167

Chao LH, Pereira LE, Vieira JP (1985) Estuarine fish community of the Patos lagoon, Brazil. A baseline study. In: YáñezArancibia A (ed) Fish Community Ecology in Estuaries and Coastal Lagoons: Towards and Ecosystem Integration, Vol. 20. UNAM, Mexico, pp 429-450

Cresson P, Bouchoucha M, Morat F, Miralles F, Chavanon F (2015) A multitracer approach to assess the spatial contamination pattern of hake (Merluccius merluccius) in the French Mediterranean. Sci Total Environ 532:184-194

De Buen F (1953) Los pejerreyes (Familia Atherinidae) en la fauna Uruguaya, con descripción de nuevas especies. B Inst Ocean São Paulo 4:3-80

de Carvalho BM, Martins Vaz-dos Santos A, Spach HL, Volpedo AV (2015) Ontogenetic development of the sagittal otolith of the anchovy, Anchoa tricolor, in a subtropical estuary. Sci Mar 79(4):409-418. https://doi.org/10.3989 /scimar.04218.31A

De La Cruz-Agüero J, García-Rodríguez FJ, De La Cruz-Agüero G, Díaz-Murillo BP (2012) Identification of Gerreid species (Actinopterygii: Perciformes: Gerreidae) from the pacific coast of Mexico based on sagittal otolith morphology analysis. Acta Ichthyol Piscat 42(4):297-306. https://doi. org/10.3750/aip2012.42.4.03

Di Dario F, Dos Santos VM, De Souza Pereira MM (2013) Range extension of Odontesthes argentinensis (Valenciennes, 1835) (Teleostei: Atherinopsidae) in the southwestern Atlantic, with additional records in the Rio de Janeiro State, Brazil. Ichthyol 30:421-423. https://doi.org/10.1111/jai.12393

Duarte-Neto P, Lessa R, Stosic B, Morize E (2008) The use of sagittal otoliths in discriminating stocks of common dolphinfish (Coryphaena hippurus) off northeastern Brazil using multishape descriptors. ICES J Mar Sci 65:1144-1152. https://doi.org/10.1093/icesjms/fsn090

Dyer BS (2000) Revisión sistemática de los pejerreyes de Chile (Teleostei, Atheriniformes). Estud Oceanol 19:99-127

Dyer BS (2006) Systematic revision of the south American silversides (Teleostei, Atheriniformes). Biocell 30:69-88

Ferguson GJ, Ward TM, Gillanders BM (2011) Otolith shape and elemental composition: complementary tools for stock discrimination of mulloway (Argyrosomus japonicus) in southern Australia. Fish Res 110:75-83. https://doi.org/10.1016/j. fishres.2011.03.014

Gagliano M, McCormick MI (2004) Feeding history influences otolith shape in tropical fish. Mar Ecol Prog Ser 278:291-296

Galley E, Wright PJ, Gibb FM (2006) Combined methods of otolith shape analysis improve identification of spawning areas of Atlantic cod. ICES J Mar Sci 63:1710-1717. https://doi.org/10.1016/j.icesjms.2006.06.014

Gauldie RW (1988) Function, form and time-keeping properties of fish otoliths. Comp Biochem Physiol A Mol Integr Physiol 91:395-402

Gauldie RW, Crampton JS (2002) An eco-morphological explanation of individual variability in the shape of the fish otolith: comparison of the otolith of Hoplostethus atlanticus with other species by depth. J Fish Biol 60:1204-1221

Harbitz A, Albert OT (2015) Pitfalls in stock discrimination by shape analysis of otolith contours. ICES J Mar Sci doi 72: 2090-2097. https://doi.org/10.1093/icesjms/fsv048

Hüssy K (2008) Otolith shape in juvenile cod (Gadus morhua): ontogenetic and environmental effects. J Exp Mar Biol Ecol 364(1):35-41

Iwata H, Ukai Y (2002) SHAPE: a computer program package for quantitative evaluation of biological shapes based on elliptical Fourier descriptors. J Hered 93:384-385

Jaramillo AM, Tombari AD, Benedito Durá V, Rodrigo Santamalia ME, Volpedo AV (2014) Otolith ecomorphological patterns of benthic fishes from the coast of Valencia (Spain). Thalassas 30(1):57-66 http://hdl.handle. net/10251/46138. Accessed 15 Feb 2019

Jawad LA, Sabatino G, Ibanez AL, Andaloro F, Battaglia P (2017) Morphology and ontogenetic changes in otoliths of the mesopelagic fishes Ceratoscopelus maderensis (Myctophidae), Vinciguerria attenuata and V. poweriae (Phosichthyidae) from the strait of Messina (Mediterranean Sea). Acta Zool 00:1-17. https://doi.org/10.1111/azo.12197

Joh M, Matsuda T, Miyazono A (2015) Common otolith microstructure related to key early life-history events in flatfishes identified in the larvae and juveniles of cresthead flounder Pseudopleuronectes schrenki. J Fish Biol 86:448-462. $\mathrm{https://doi.org/10.1111/jfb.12562}$

Lleonart J, Salat J, Torres GJ (2000) Removing allometric effects of body size in morphological analysis. J Theor Biol 205:8593. https://doi.org/10.1006/jtbi.2000.2043

Llompart FM, Colautti DC, Baigún CRM (2012) Assessment of a major shore-based marine recreational fishery in the Southwest Atlantic, Argentina. New Zeal J Mar Fresh 46: 57-70. https://doi.org/10.1080/00288330.2011.595420

Llompart FM, Colautti DC, Maiztegui T, Cruz-Jimenez AM, Baigún CRM (2013) Biological traits and growth patterns of Pejerrey Odontesthes argentinensis. J Fish Biol 82:458474. https://doi.org/10.1111/j.1095-8649.2012.03494.x 
Llompart FM, Colautti DC, Baigún CRM (2017) Conciliating artisanal and recreational fisheries in Anegada Bay, Argentina. Fish Res 190:140-149. https://doi.org/10.1016/j. fishres.2017.01.011

Lombarte A, Castellón A (1991) Interespecific and intraspecific otolith variability in the genus Merluccius as determined by image analysis. Can J Zool 69:2442-2449

Lombarte A, Tuset V (2015) Morfometria de otolitos. Métodos de estudo com otólitos: principíos e aplicações. Buenos Aires: CAFP-BA-PIESCI, 269-302

Lombarte A, Torres GJ, Morales-Nin B (2003) Specific Merluccius otolith growth patterns related to phylogenetics and environmental factors. J Mar Biol Assoc U K 83(2):277281

Lombarte A, Palmer M, Matallanas J, Gómez-Zurita J, MoralesNin B (2010) Ecomorphological trends and phylogenetic inertia of otolith sagittae in Nototheniidae. Environ Biol Fish 89:607-618. https://doi.org/10.1007/s10641-010-96732

Longmore C, Fogarty K, Neat F, Brophy D, Trueman C, Milton A, Mariani S (2010) A comparison of otolith microchemistry and otolith shape analysis for the study of spatial variation in a deep-sea teleost, Coryphaenoides rupestris. Environ Biol Fish 89:591-605. https://doi.org/10.1007/s10641-010-96741

Martinetto P, Iribarne O, Palomo G (2005) Effect of fish predation on intertidal benthic fauna is modified by crab bioturbation. $\mathrm{J}$ Exp Mar Biol Ecol 318:71-84. https://doi.org/10.1016/j. jembe.2004.12.009

Mohan JA, Rulifson RA, Corbett DR, Halden NM (2012) Validation of Oligohaline elemental otolith signatures of striped bass by use of in situ caging experiments and water chemistry. Mar Coast Fish 4(1):57-70. https://doi. org/10.1080/19425120.2012.656533

Monteiro LR, Di Beneditto APM, Guillermo LH, Rivera LA (2005) Alometric changes and shape differentiation of sagitta otoliths in sciaenid. Fish Res 74:288-299

Morales-Nin BYO (1987) The influence of environmental factors on microstructure of otoliths of three demersal fish species caught off Namibia. In: Payne, A.I.L., Gulland, J.A., Brink, K.H. (Eds.), The Benguela and Comparable Ecosystems. S Afr J Mar Sci 5:255-262

Orlov AM, Afanasyev PK (2013) Otolith morphometrics as a tool for analysis of the population structure of Pacific cod Gadus macrocephalus (Gadidae, Teleostei) Amur Zool Zh 3:327331

Petursdottir G, Begg GA, Marteinsdottir G (2006) Discrimination between Icelandic cod (Gadus morhua L.) populations from adjacent spawning areas based on otolith growth and shape fish res 80:182-189. https://doi.org/10.1016/j. fishres.2006.05.002

Piera J, Parisi-Baradad V, García-Ladona E, Lombarte A, Recasens L, Cabestany J (2005) Otolith shape feature extraction oriented to automatic classification with open distributed data. Mar Freshw Res 56(5):805-814

Ponton D (2006) Is geometric morphometrics efficient for comparing otolith shape of different fish species? J Morphol 267(6):750-757. https://doi.org/10.1002/jmor.10439

Popper AN, Ramcharitar J, Campana SE (2005) Why otoliths? Insights from inner ear physiology and fisheries biology. Mar Freshw Res 56(5):497-504
Radtke RL, Shafer DJ (1992) Environmental sensitivity of fish otolith microchemistry. Aust J Mar Freshw Res 43:935-951

Rohlf JF, Marcus LF (1993) A revolution morphometrics. Trends Ecol Evol 8(4):129-132

Sadighzadeh Z, Otero-Ferrer JL, Lombarte A, Fatemi MR, Tuset VM (2014) An approach to unraveling the coexistence of snappers (Lutjanidae) using otolith morphology. Sci Mar 78: 353-362

Sampaio LA (2006) Production of "pejerrey" Odontesthes argentinensis fingerlings: a review of current techniques. Biocell 30(1):121-123

Silva Rodríguez MP, Favero M, Berón MP, Mariano-Jelicich R, Mauco L (2005) Ecology and conservation of seabirds using the coasts of Buenos Aires Province as a wintering area. El hornero 20(1):111-130

Steer MA, Fowler AJ (2014) Spatial variation in shape of otoliths for southern garfish Hyporhamphus melanochir-contribution to stock structure. Mar Biol Res 11:23-33. https://doi. org/10.1080/17451000.2014.952313

Thompson GA, Volpedo AV (2018) Diet composition and feeding strategy of the New World silverside Odontesthes argentinensis in a temperate coastal area (South America). Mar Coast Fish 10:80-88

Tombari A, Volpedo AV, Echeverría DD (2005) Desarrollo de la sagitta en juveniles y adultos de Odontesthes argentiniensis (Valenciennes, 1835) y O. bonariensis (Valenciennes, 1835) de la provincia de Buenos Aires, Argentina (Teleostei: Atheriniformes). Rev Chil Hist Nat 78:623-633

Tombari A, Gosztonyi A, Echeverría DD, Volpedo AV (2010) Otolith and vertebral morphology of marine atherinid species (Atheriniformes, Atherinopsidae) coexisting in the southwestern Atlantic Ocean. Cienc Mar 36(3):213-223

Tracey SR, Lyle JM, Duhamel G (2006) Application of elliptical Fourier analysis of otolith form as a tool for stock identification. Fish Res 77:138-147

Turan C (2000) Otolith shape and meristic analysis of herring (Clupea harengus) in the north-East Atlantic. Arch Fish Mar Res 48(3):213-225

Tuset VM, Lombarte A, González JA, Pertusa JF, Lorente M (2003a) Comparative morphology of the sagittal otolith in Serranus spp. J Fish Biol 63(6):1491-1504

Tuset VM, Lozano IJ, González JA, Pertusa JF, García-Díaz MM (2003b) Shape indices to identify regional differences in otolith morphology of scomber, Serranus cabrilla (L., 1758). J Appl Ichthyol 19(2):88-93. https://doi.org/10.1046 j.1439-0426.2003.00344.x

Tuset VM, Imondi R, Aguado G, Otero-Ferrer JL, Santschi L, Lombarte A, Love M (2015) Otolith patterns of rockfishes from the northeastern Pacific. J Morphol 276(4):458-469

Valentin AE, Peninc X, Chanutb JP, Powerd D, Sévignya JM (2014) Combining microsatellites and geometric morphometrics for the study of redfish (Sebastes spp.) population structure in the Northwest Atlantic. Fish Res 154:102-119

Vasconcelos J, Vieira AR, SequeiraV GJA, Kaufmann M, Gordo LS (2018) Identifying populations of the blue jack mackerel (Trachurus picturatus) in the Northeast Atlantic by using geometric morphometrics and otolith shape analysis. Fish Bull 116:81-92

Vignon M (2012) Ontogenetic trajectories of otolith shape during shift in habitat use: interaction between otolith growth and environment. J Exp Mar Biol Ecol 420:26-32 
Vignon M, Morat F (2010) Environmental and genetic determinant of otolith shape revealed by a non-indigenous tropical fish. Mar Ecol Prog Ser 411:231-241

Volpedo AV, Echeverría DD (1999) Morfología de los otolitos sagittae de juveniles y adultos de Micropogonias furnieri (Desmarest, 1823) (Sciaenidae). Revista de Ciencias Mar Thalassas 15:19-24

Volpedo AV, Echeverría DD (2003) Ecomorphological patterns of the sagitta in fish on the continental shelf off argentine. Fish Res 60(2):551-560

Volpedo AV, Vaz dos Santos AM (2015) Métodos de estudios con otolitos: principios y aplicaciones/ Métodos de estudos com otólitos: princípios e aplicações $-1^{\text {era }}$ ed. edición bilingue. Ciudad Autónoma de Buenos Aires ISBN 978-987-33-8884-2
Volpedo AV, Tombari AD, Echeverría DD (2008) Ecomorphological patterns of the sagitta of Antarctic fish. Polar Biol 31:635-640. https://doi.org/10.1007/s00300-007-0400-1

Waessle JA, Lasta CA, Favero M (2003) Otolith morphology and body size relationships for juvenile Sciaenidae in the Río de la Plata estuary $\left(35-36^{\circ} \mathrm{S}\right)$. Sci Mar 67(2):233-240

Wilson RR Jr (1985) Depth-related changes in sagitta morphology in six Macrourid fishes of the Pacific and Atlantic oceans. Copeia 1985:1011-1017

Wu Q, Merchant F, Castleman K (2008). Microscope image processing. Elsevier. 548 pp.

Publisher's note Springer Nature remains neutral with regard to jurisdictional claims in published maps and institutional affiliations. 